\title{
JUVENILE HUNTINGTON'S DISEASE CONFIRMED BY GENETIC EXAMINATION IN TWINS
}

\author{
GILBERTO LEVY*, MARIA EDUARDA NOBRE**, VINICIUS T. CIMIN/***, \\ SALMO RASKIN****, ELIASZ ENGELHARDT*****
}

\begin{abstract}
Early-onset Huntington's disease (HD) occurs in approximately 10\% of HD's cases. We report juvenile HD in phenotypically identical twins, evaluated by history, clinical and neurologic examination, minimental state examination, blood laboratory exams, cerebrospinal fluid examination, skull computed tomography, and genetic examination for HD. Patients had the akinetic-rigid variety (Westphal variant) of the disease and paternal inheritance. The laboratory workup confirmed the clinical diagnosis of HD, which adds this report to the rare cases of $\mathrm{HD}$ in twins reported in the literature.
\end{abstract}

KEY WORDS: Huntington's disease, juvenile, twins.

\section{Doença de Huntington juvenil confirmada por exame genético em gêmeas}

RESUMO - Doença de Huntington (DH) de início precoce ocorre em aproximadamente $10 \%$ dos casos de DH. Relatamos DH juvenil em gêmeas fenotipicamente idênticas, avaliadas por história, exames clínico e neurológico, mini-exame do estado mental, exames de sangue, exame do líquido cefalorraquidiano, tomografia computadorizada de crânio e exame genético para $\mathrm{DH}$. As pacientes apresentavam a variedade rígido-acinética (variante de Westphal) da doença e herança paterna. A avaliação laboratorial confirmou o diagnóstico clínico de $\mathrm{DH}$, acrescentando-se este relato aos raros casos de $\mathrm{DH}$ em gêmeos relatados na literatura.

PALAVRAS-CHAVE: doença de Huntington, juvenil, gêmeos.

Huntington's disease (HD) is an autossomal dominant hereditary disorder with complete penetrance, in which the genetic mutation is localized on the short arm of chromossome 4 (4p16.3), consisting of a sequence of more than 34 repeats of the trinucleotide $\mathrm{CAG}^{1,2}$. The age of onset of the disease is inversely proportional to the number of CAG repeats and the expansion of the trinucleotide sequence is related to the anticipation phenomenon (earlier onset and/or more severe expression in successive generations) observed in affected families ${ }^{2}$.

Juvenile HD is defined as beginning before the arbitrarily chosen age of 21 years ${ }^{3}$; it occurs in approximately $10 \%$ of HD's patients and 80 to $90 \%$ of these inherit the disease from their fathers ${ }^{4}$. In general, the symptoms are more severe and more rapidly progressive with early onset ${ }^{5,6}$. We report phenotypically identical twins with early-onset disease confirmed by genetic examination.

\section{CASES REPORT}

Patients were female, 24 years-old when first examined, and phenotypically identical (Fig 1A). The onset of their disease, as reported by relatives, was at 17 and 20 years of age, the initial manifestations being

Instituto de Neurologia Deolindo Couto, Universidade Federal do Rio de Janeiro (UFRJ), Rio de Janeiro, Brasil: *Medical Staff; **Ex-Resident, Post-Graduate Student of Universidade Federal Fluminense (UFF); $* * *$ Resident; ****Geneticist, Laboratório Genetika; *****Associate Professor. Aceite: 16-junho-1999.

Dr. Gilberto Levy - Av. Delfim Moreira 90/201 - 22441-000 Rio de Janeiro RJ - Brasil. 
balance and gait impairment with a progressive course. Neurologic examination showed bradykinesia, rigidity with cogwheel phenomenon, choreic movements of trunk and limbs (mild degree), dysarthria, hyperactive tendon reflexes and flexor plantar responses. The patient with earlier onset of the disease was more severely affected. Neurologic examination was repeated approximately six months and one year after the initial examination, and both patients worsened on each successive examination.

Mini-mental state examination scores were $19 / 30$ and 18/30, both of them having less than eight years of formal education. Serum copper and ceruloplasmin, as well as routine cerebrospinal fluid examination, were normal. Skull computed tomography of both patients showed bilateral caudate atrophy (Fig 1B e 1C).

Genetic examination showed an increased number of the CAG trinucleotide in one allele: there were 61 and 62 repeats in one allele and 22 repeats in the other allele of each patient (normal: 11 to 34 repeats). Laboratory confirmation of monozygosity was not performed.

Regarding the family history, their father had a similar neurologic picture beginning at 39 years of age (died at 44 years of age) and their grandmother had a "mental disorder" late in life. The patients had four siblings, aged 26 to 30 years, who were reportedly normal and no other relative was known to have the disease.

\section{DISCUSSION}

In 1960, Myrianthopoulos and Rowley ${ }^{7}$ presented the fist case of monozygotic twins concordant for HD in whom monozygosity had been documented, and reviewed the previous literature (about 20 cases of chorea in twins, eight of these allegedly in identical twins). Other cases of HD in identical twins were reported in a family whose members also presented epilepsy (the twins presented both epilepsy and $\mathrm{HD})^{8}$, and in a family expressing the childhood and adult rigid variants of the disease ${ }^{9}$. Bachman et al. ${ }^{10}$ described identical twins with juvenile HD, beginning at the age of 5 and showing paternal inheritance. In 1983, Sudarsky et al. ${ }^{11}$ identified 13 sets of monozygotic twins in the literature, eight sets presumed to be identical by physical characteristics and five proved identical serologically.

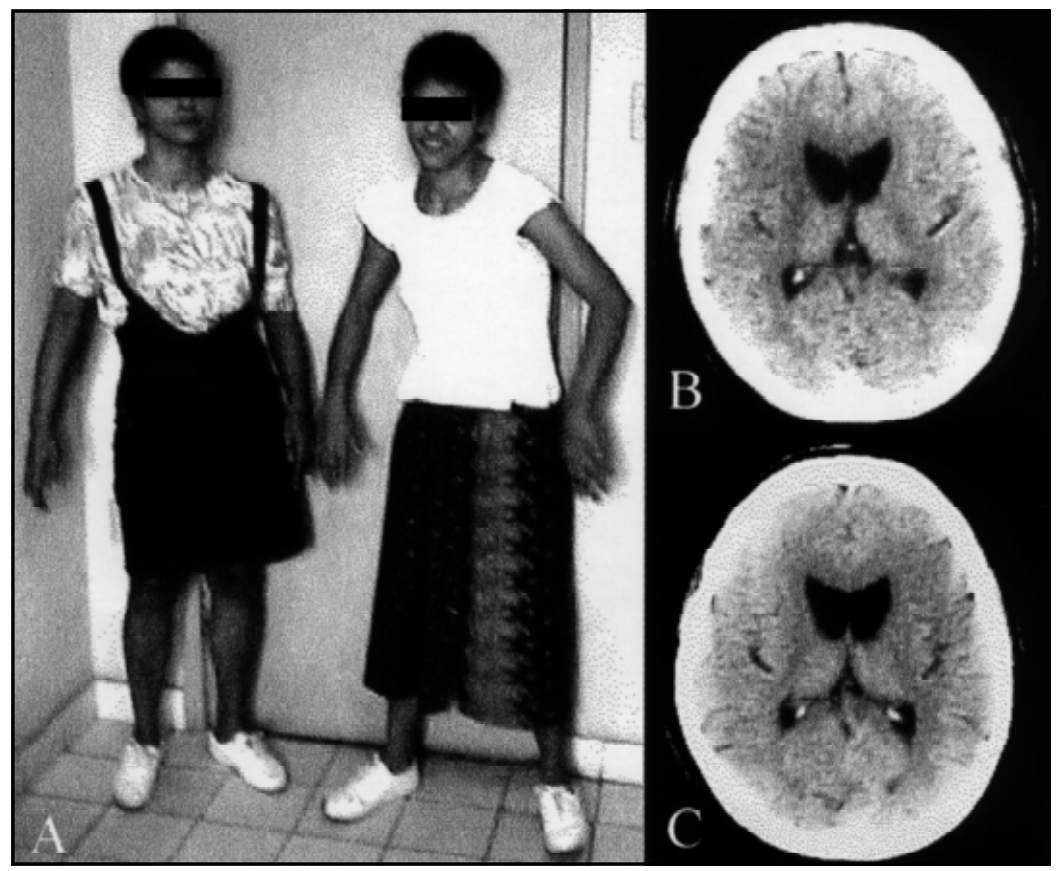

Fig 1. Phenotipically identical twins (A) and skull computed tomography showing head of caudate nucleus atrophy (B and $C$ ). 
The laboratory workup in our cases confirmed the clinical diagnosis of HD, which adds one report to the rarely reported cases of HD in twins. Besides, the patients reported correspond to juvenile cases. In accordance with the literature on juvenile $\mathrm{HD}^{3,4}$, the patients had the akinetic-rigid variety (Westphal variant) of the disease and paternal inheritance. Although we have not examined the affected relatives of other generations, anticipation phenomenon in three successive generations of this family seems to have occurred.

MacDonald et al. ${ }^{12}$ studied four pairs of monozygotic twins who displayed identical CAG repeat lenghts, and suggested that repeat lenght instability occurred in gametogenesis. The slight difference in the results of the genetic examination in our cases, supposing they are monozygotic twins, may be attributed to a limitation of the technique. On the other hand, this difference would not account for the differential clinical features, since the patient with earlier onset and more severe motor impairment was the one with 61 repeats in one allele.

No symptomatic treatment was tried in our patients. On the basis of the demonstrated reduction of gamma-amino-butyric acid (GABA) in the basal ganglia of patients with HD, dipropylacetic acid (valproic acid), whose proposed mode of action is to increase central nervous system GABA, has been administered to identical twins with rigid-akinetic HD, without short- or long-term benefits ${ }^{10}$.

The age of onset in HD has been found to show greater similarities within sibships than between sibships ${ }^{5}$. Interestingly, our patients had different ages of onset of the disease and different severity of motor symptoms. The twins reported by Bird and Omenn" showed "a marked difference in clinical expression of the disease"; according to these authors, in each set of twins the mental deterioration was more similar and consistent and the movement disorder was more variable. Sudarsky et al. ${ }^{11}$ noted the "striking similarity" in the age of onset of choreiform movement and in the nature of behavioral manifestations in monozygotic twins reared apart; however, one of the twins exhibited the first behavioral symptoms 9 years before the other. These authors remarked that the difference within each pair of identical twins in age of onset ranged from 0 to 3 years, concluding that clinical features were "substantially determined by genetic mechanisms". Additionally, these clinical differences may be viewed as suggesting environmental factors playing a part in the expression of the disease.

\section{REFERENCES}

1. Fahn S. Huntington disease. In Rowland LP (ed). Merritt's textbook of neurology. 9Ed. Baltimore: Williams \& Wilkins, 1995:695-699.

2. Milunsky JM, Milunsky A. Genetic counseling in perinatal medicine. Obst Gynecol Clin N Am 1997;24:1-17.

3. Van Dijk JG, Van Der Velde EA, Ross RAC, Bruyn GW. Juvenile Huntington disease. Hum Genet 1986;73:235-239.

4. Butler IJ. Movement disorders of children. Pediatr Clin N Am 1992;39:727-742.

5. Rainer JD. Chronological parameters, twin studies, and mental diseases. Acta Genet Med Gemellol 1971;20:359-372.

6. Caviness VS. Huntington's disease. Dev Med Child Neurol 1985;27:826-829.

7. Myrianthopoulos NC, Rowley PT. Monozygotic twins concordant for Huntington's chorea. Neurology 1960;10:506-511.

8. Schiottz-Christensen E. Huntington chorea and epilepsy in monozygotic twins. Eur Neurol 1969;2:250-255.

9. Bird TD, Omenn GS. Monozygotic twins with Huntington's disease in a family expressing the rigid variant. Neurology 1975;25:1126-1129.

10. Bachman DS, Butler IJ, McKhann GM. Long-term treatment of juvenile Huntington's chorea with dipropylacetic acid. Neurology 1977;27:193-197.

11. Sudarsky L, Myers RH, Walshe TM. Huntington's disease in monozygotic twins reared apart. J Med Genet 1983;20:408411.

12. MacDonald ME, Barnes G, Srinidhi J, et al. Gametic but not somatic instability of CAG repeat lenght in Huntington's disease. J Med Genet 1993;30:982-986. 